\title{
EVALUATION OF WATER POLLUTED WITH NITRITE ON EGG PRODUCTION AND SOME HEMATOBIOCHEMICAL PARAMETERS IN LAYING HENS FARMS
}

\author{
EMAN, I. M. ISMAIL ${ }^{1}$; OSAMA E. RAMDAN ${ }^{1}$; MAGDA N. ABD EL HAMID ${ }^{1}$; \\ EL-NILE, M.B. ${ }^{1}$; NAHED A.KAMOURA ${ }^{2}$ AND SANNA M. SALEM ${ }^{3}$ \\ ${ }^{1}$ Department Biochemistry, Animal Health Research Institute (Zagazig Branch) \\ ${ }^{2}$ Department Clinical Pathology, Animal Health Research Institute (Zagazig Branch) \\ ${ }^{3}$ Department Histopathology Animal Health Research Institute (Zagazig Branch)
}

Received: 14 September 2020; Accepted: 5 October 2020

\begin{abstract}
This study was designed to determine adverse effect of nitrite on some hematobiochemical parameters and egg production in laying hens. Sample from underground well water from different region in Sharkia province (Diarp Negm, Kafr Sakr, El Salhia and Zagazig) was examined for detection nitrite level. Analysis of water sample revealed presence of nitrite in level of 0.34, 0.013, 0.05 and 0.63 ppm nitrite in Zagazig, Diarp Negm, Kafr Saker and El Salhia Cities. A total of 60 laying hens (22 week age) were divided into 3 equal groups (20 of each). First group laying hens received one liter of water contains $1 \mathrm{mg}$ nitrite/liter for 30 day (control group), second group laying hens received one liter of water contains $4 \mathrm{mg}$ nitrite/lite for 30 day and third group laying hens received one liter of water contains $8 \mathrm{mg}$ nitrite/lite for 30 days. At $1^{\text {st }}$ day post supplementation three blood samples were collected from 5 birds for hematobiochemical study. Hens received one liter of water contains $4 \mathrm{mg}$ sodium nitrite/liter drinking water for 30 days showed non-significant reduction in RBCs, Hb, PCV, MCHC, WBCs, lymphocyte, Phagocytosis, total protein, albumin, globulin and egg production and Calcium beside insignificant increase in MCV, MCH, Platelet count, heterophils, AST, ALT, ALP, uric acid and creatinine. Meanwhile hens received one liter of water contains $8 \mathrm{mg}$ nitrite/liter show significant reduction in RBCs, Hb, PCV, MCHC, WBCs, lymphocyte, Phagocytosis, total protein, albumin, globulin, egg production\%, egg weight, Shell thicknes, Egg shell weight and Calcium beside significant increase in MCV, MCH, Platelet count, heterophils, AST, ALT, ALP, uric acid and creatinine. Residues of nitrite in liver and kidney beside its dose dependent laying hens received one liter of water contains $0.1 \%$ sodium nitrite showed normal histological structures in all body organs (liver, Kidney and spleen) but laying hens received one liter of water contains $4 \%$ and one liter of water contains $8 \%$ sodium nitrite showed moderate to severe lesion in liver, Kidney and spleen. It could be concluded that high nitrite in water induce alterations in hematobiochemical parameters and egg production as well as pathological lesions. So, it is recommended not use water contains high level of nitrite in laying hens farms.
\end{abstract}

Key words: Water Pollution by Nitrite - Hematololgy- Biochemistry- Egg production-Laying hens.

\section{INTRODUCTION}

Water is vital to life of the organism that water content of the body be

Corresponding author: EMAN, I. M. ISMAIL E-mail address: dr.emanismail201@gmail.com Present address: Department Biochemistry, Animal Health Research Institute (Zagazig Branch) maintained, an animal will die more rapidly if deprived of water than if deprived of food (Mc Donald et al., 2002). Water help to maintain homeostasis and control $\mathrm{pH}$, osmotic pressures and other functions necessary for life (Scott et al., 1982). Environmental pollution is deleterious of biological life. Chemical Pollution 
(pesticides, heavy metals, organic compounds, toxic gases and fumes) widely spread and threatens biological balance (Forstner and Wittman, 1983). Pure water does not exist in nature (Jennings et al., 1996). Water pollution is one of world problems, which results from increased population growth, urbanization and industrialization (Ma et al., 2009). Rain water collect impurities while passing through air, dangerous products from industry and agriculture reaches the rivers, lakes, and underground water (Salem et al., 2000).

Sodium nitrite is important antimicrobial, flavoring, coloring and preservative agent in meat. Nitrite may cause methemoglobinemia (Gihan et al., 2014). Nitrite is formed naturally by nitrogen cycle during process of nitrogen fixation and possess mutagenic, teratogenic and embryotoxic. Two main nitrite salt forms occur, sodium and potassium nitrite (Atef $e t$ al., 1991). Nitrite is a natural body constituent and is important for biological functions (Jensen, 2007) which performs a major role in immunology (Lundberg et al., 2008). High levels of nitrite is considered a toxic as it can bring about physiological disturbances effects upon health, including impairment of reproductive function, endocrine disturbances and hepatorenal toxicity (Abu Aita and Mohammed 2014). Nitrite toxicity may be attributed to its potency to produce oxidative stress (Ansari et al., 2015). Low levels of nitrite may play a potential role as an antioxidant and has several health benefits (McNally et al., 2016).

Nitrites are used as human food additives mainly for production of specific flavor and for preservation of meat products. Several organic nitrites have been used clinically but only inorganic nitrites of therapeutic are sodium nitrite (Heibashy and Abd El Moneim, 1999). Nitrites and nitrates are environmental pollutants present in food and water and it is suggested that they may contribute to the etiology of liver and kidney diseases and problems related of immunity in domestic fowls (Ibrahim et al., 1999).

The objective of this study is to determine the effect of Nitrites on egg production, blood picture and blood biochemistry in laying hens and associated with pathological change.

\section{MATERIALS AND METHODS}

\section{Water samples and Chemical analysis}

Underground well water samples (one liter of water) from Zagazig, Diarp Negm, Kafr Sakr and El Salhia Cities areas were collected for detection of $\mathrm{Ph}$ calculated by jenway apparatus ( $\mathrm{pH}$ meter) model number 3510. Nitrite was determined used spectrophotometer model 690 according to Haimin et al. (2016). Total dissolved solid were analyzed according (APHA, 1999) and calculated according to equation

$$
\mathrm{W}_{1}-\mathrm{W}_{2} \mathrm{X} 10
$$

Where $\mathrm{W}_{1}$ weight of empty flask

$\mathrm{W}_{2}$ weight of flask after heating with $100 \mathrm{ml}$ water untill boiling then evaportatd all water and remining salt only

\section{Birds and Experimental design}

About 60 laying hens, 22 week age were divided into 3 equal groups (20 each). First group hens received one liter of water contains $1 \mathrm{mg}$ nitrite/liter drinking water for 30 day (control group), second group hens received one liter of water contains $4 \mathrm{mg}$ nitrite/liter drinking water for 30 day (Safary and Daneshyar, 2012) and third group hens received one liter of water contains 8mg nitrite/liter drinking water for 30 day with (Eman and Fahm 2006).

\section{Blood samples}

At $1^{\text {st }}$ day post supplementation 5 laying hens from each group were selected and three blood samples were collected.

First sample was taken on tube contain EDTA for estimation blood picture (Jain, 1993).

Second sample was taken in tube contain heparin for estimation phagocytosis

Heparinized blood samples used for phagocytosis assay:- 
a. Separation of Peripheral Blood Mononuclear Cells (PBMC) using ficollplaque density gradient was carried out (Boyum, 1986 and Godeeris et al., 1986).

b. Phagocytic assay (Wilikinson, 1976).

c. Measurement of phagocytic activity of Peripheral Blood Monocyte (PBM) using Candida albicans was performed (Anthony et al., 1985 and Chu and Dietert, 1989).

d. Evaluation of phagocytic activity (Wilikinson, 1976).

Third samples was taken without anticoagulant for estimation (AST and ALT) (Ritman and Frankle 1957), ALP (John 1982), total protein (Doumas et al., 1981), albumin (Bauer, 1982), globulin (Kapale, 2008), uric acid (Coalombe and Faurean 1963), creatinine (Husdan and Roporpot, 1968) and calcium (Gindler 1972)

\section{Egg production, egg weight and Shell thickness}

Egg produced by each groups were collected during and $1^{\text {st }}$ month post supplementation for recorded egg production\% and egg weight and Shell thickness (Summers et al., 1976).

\section{Examination}

Specimens were taken from liver, kidneys, intestine, spleen and bursa of the sacrificed duckling and directly fixed in $10 \%$ neutral buffered formalin. Five-micron thick paraffin sections were prepared stained with hematoxylin and eosin and examined microscopically (Bancroft and Gamble, 2002).

\section{Measurements of tissue nitrite in liver and kidney}

Residues of nitrite in liver and kidney were determined according method described by (Carlstrom et al., 2010)

\section{Statistical analysis}

Statistical analysis was performed using analysis of variance (ANOVA). Duncan's Multiple Range Duncan, (1955) was used to determine differences among treatments mean at significance level of 0.05. Statistics were run using SPSS program (SPSS 2004)

\section{RESULTS}

Analysis of underground well waters from different region in Sharkia Province revealed levels of $\mathrm{PH}$, total dissolved solid and nitrite in Diarp Negm were 8.28, 608 and 0.013, Kafr Sakr 8.46, 207.25, 0.05, El Salhia, 8.69, 722.5, 0.63 and Zagazig, 9.85, 1764.33, 34 ppm respectively table (1).

The obtained results for some egg parameters were summarized in table (4). The results revealed laying hens received one liter of water contains $8 \mathrm{mg}$ sodium nitrate/liter drinking water decreased egg production $\%$, egg weight, shell thickness and shell weight.

Hens received one liter of water contains $4 \mathrm{mg}$ sodium nitrite/liter drinking water for 30 days showed non-significant reduction in RBCs, $\mathrm{Hb}, \mathrm{PCV}, \mathrm{MCHC}$, WBCs, lymphocyte, Phagocytosis, total protein, albumin, globulin and egg production and Calcium beside insignificant increase in MCV, MCH, Platelet count, neutrophils, AST, ALT, ALP, uric acid and creatinine. Meanwhile hens received one liter of water contains $8 \mathrm{mg}$ nitrite/liter show significant reduction in $\mathrm{RBCs}, \mathrm{Hb}, \mathrm{PCV}, \mathrm{MCHC}$, WBCs, lymphocyte, Phagocytosis, total protein, albumin, globulin, egg production\%, egg weight, Shell thickness, Egg shell weight and Calcium beside significant increase in $\mathrm{MCV}, \mathrm{MCH}$, Platelet count, neutrophils, AST, ALT, ALP, uric acid and creatinine table(3).

Residues of nitrite in liver and kidney is dose dependent, Table (5) showed that the nitrite residues were detected in high levels in kidney more than liver post administration.

Gross pathological lesion appeared in laying hens received one liter of water contains $0.1 \%$ sodium nitrite showed liver, Kidney and spleen normal histological characterization of different structures but laying hens received one liter of water contains $4 \%$ and one liter of water contains 
$8 \%$ sodium nitrite showed sever lesion in liver, Kidney and spleen.

Residues of nitrite in liver and kidney is dose dependent, Table, (5) showed nitrite residues were detected in high levels in kidney more that liver post supplementation.

Sodium nitrite in dose $1 \mathrm{mg} /$ liter water showed normal histological structures of different organ. Liver, portal area, hepatocytes were seen small masses around central veins. a few round cells were seen as a natural immune response around portal area (Fig. 1 A, B) Kidney showed normal nephron, including tubular structures, Uri nephric duct and avian glomeruli. The stromal and vascular structures were apparently normal. (Fig.1C, D). Spleen showed normal white and red pulp with central arteriole, germinal centers and red pulp sinusoids with their reticulioendothelial linings. (Fig.1 E, F)

Hens received one liter of water contains 4mg sodium nitrite /liter show: Liver dilated, congested poenrtal blood vessels, moderate biliary proliferation, portal round cells aggregations and predominance of eosinophils in some areas (Fig 2. A,B). Scale bars 50 um, 25um Kidney (Fig 2. C,
D). Renal vascular congestion, tubular degeneration, focal tubular hyperplasia and focal glomerular endothelial cellular proliferation. Scale bars $50 \mathrm{um}, 25 \mathrm{um}$. Spleen (Fig. 2. E, F). Moderate germinal centers hyperplasia and peri-arteriolar sheath lymphoid proliferation with a normal structurally organized Red pulp. Scale bars 50 um, 25 um

Hens received one liter of water contains 8 sodium nitrite/liter Liver show hepatic portal round cells aggregations, biliary proliferative hyperplasia with focal metaplastic change together with portal Fibroplasia and infiltration of eosinophils. Interstitial round cells aggregations, eosinophils infiltration and hepatocellular degeneration and individual cellular apoptosis. (Fig. 3 A, B). Kidney. Show peri-vascular edema, intestinal hemorrhages perivascular and interstitial round cell aggregations and renal tubular degeneration with focal necrotic changes (Fig.3 C, D). Spleen showed germinal centers hyperplasia and peri-arteriolar sheath lymphoid proliferation, diffuse replacement of red pulp by mature and immature lymphocytic and eosinophils infiltration. (Fig.3 E, F).

Table (1): Analysis of underground well water in different centers in Sharkia Governorate $(n=5)$.

\begin{tabular}{ccccc}
\hline Centers & Zagazig & Kafr Sakr & El Salhia & Diarp Negm \\
\hline PH & $9.85 \pm 0.87$ & $8.46 \pm 0.98$ & $8.69 \pm 0.79$ & $8.28 \pm 0.83$ \\
\hline Total dissolved solid & $1764.33 \pm 3.18$ & $207.25 \pm 2.37$ & $722.5 \pm 3.94$ & $608 \pm 2.58$ \\
\hline Nitrite(ppm) & $0.34 \pm 0.05$ & $0.05 \pm 0.004$ & $0.63 \pm 0.12$ & $0.013 \pm 0.006$ \\
\hline
\end{tabular}

Table (2): Effect of sodium nitrite on blood picture and phagocytosis in laying hens $(\mathrm{N}=5)$

\begin{tabular}{|c|c|c|c|c|c|}
\hline \multicolumn{3}{|c|}{ Groups } & 1mg nitrite & $4 \mathrm{mg}$ nitrite & $8 \mathrm{mg}$ nitrite \\
\hline \multirow{6}{*}{ 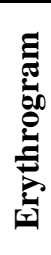 } & \multicolumn{2}{|c|}{$\operatorname{RBCs}\left(\times 10^{6}\right)$} & $4.20 \pm 0.65 \mathrm{a}$ & $3.90 \pm 0.65 \mathrm{a}$ & $2.52 \pm 0.65 b$ \\
\hline & \multicolumn{2}{|c|}{$\mathrm{Hb}(\mathrm{g} / \mathrm{dl})$} & $9.40 \pm 0.92 \mathrm{a}$ & $8.60 \pm 0.65 a$ & $6.00 \pm 0.92 b$ \\
\hline & \multicolumn{2}{|c|}{ PCV (\%) } & $27.78 \pm 2.14 \mathrm{a}$ & $26.74 \pm 0.65 a$ & $19.24 \pm 2.14 b$ \\
\hline & \multirow{3}{*}{ T⿱乛龰己 } & $\mathrm{MCHC}(\%)$ & $35.94 \pm 1.21 \mathrm{a}$ & $35.57 \pm 0.65 a$ & $32.77 \pm 1.21 \mathrm{~b}$ \\
\hline & & $\mathrm{MCH}(\mathrm{Pg})$ & $27.63 \pm 1.20 \mathrm{~b}$ & $28.48 \pm 0.65 b$ & $30.53 \pm 1.20 \mathrm{a}$ \\
\hline & & $\mathrm{MCV}(\mathrm{FL})$ & $31.85 \pm 1.12 b$ & $33.22 \pm 0.65 b$ & $36.22 \pm 0.65$ \\
\hline & \multicolumn{2}{|c|}{ Platelet $(103 / \mathrm{cmm})$} & $268.23 \pm 2.14 b$ & $269.45 \pm 0.65 b$ & $284.18 \pm 2.14 a$ \\
\hline \multirow{7}{*}{ 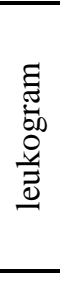 } & Tot & count $10^{3} / \mathrm{cm}$ & $9.21 \pm 0.41 \mathrm{a}$ & $8.51 \pm 0.23 a$ & $9.21 \pm 0.43 \mathrm{a}$ \\
\hline & \multirow{5}{*}{ 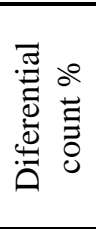 } & Heterophils & $28.03 \pm 0.39 b$ & $51.03 \pm 0.26 \mathrm{a}$ & $39.23 \pm 0.21 \mathrm{a}$ \\
\hline & & Lymphoyte & $52.12 \pm 0.23 a$ & $51.03 \pm 0.26 a$ & $48.06 \pm 0.42 b$ \\
\hline & & Eosinophils & $3.11 \pm 0.19 a$ & $2.15 \pm 0.21 \mathrm{a}$ & $2.03 \pm 0.11 \mathrm{a}$ \\
\hline & & Basophils & $3.20 \pm 0.16 \mathrm{a}$ & $2.03 \pm 0.26 \mathrm{a}$ & $1.07 \pm 0.27 \mathrm{~b}$ \\
\hline & & Monocyte & $13.41 \pm 0.21 \mathrm{~b}$ & $13.41 \pm 0.21 b$ & $8.08 \pm 0.18 \mathrm{a}$ \\
\hline & \multicolumn{2}{|c|}{ Phagocytosis (\%) } & $22.32 \pm 0.33 a$ & $21.42 \pm 0.40 \mathrm{a}$ & $19.61 \pm 0.34 b$ \\
\hline
\end{tabular}


Table (3): Effect of sodium nitrite on liver and kidney functions in laying hens $(\mathrm{n}=5)$

\begin{tabular}{|c|c|c|c|c|c|}
\hline \multicolumn{3}{|c|}{ Groups } & $1 \mathrm{mg}$ nitrite/liter & $4 \mathrm{mg}$ nitrite/liter & $8 \mathrm{mg}$ nitrite/liter \\
\hline \multirow{7}{*}{ 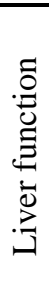 } & \multirow{3}{*}{$\begin{array}{c}\text { Liver } \\
\text { enzymes } \\
(\mathrm{u} / \mathrm{l})\end{array}$} & ALT & $18.34 \pm 0.89 b$ & $19.18 \pm 0.95 b$ & $25.09 \pm 0.89 a$ \\
\hline & & AST & $53.18 \pm 0.78 b$ & $55.34 \pm 0.98 b$ & $59.18 \pm 0.78 \mathrm{a}$ \\
\hline & & $\overline{\mathrm{ALP}}$ & $31.21 \pm 0.88 \mathrm{~b}$ & $31.21 \pm 0.88 \mathrm{~b}$ & $37.26 \pm 0.98 \mathrm{a}$ \\
\hline & \multirow{4}{*}{$\begin{array}{l}\text { Protein } \\
\text { picture } \\
(\mathrm{gm} / \mathrm{dl}\end{array}$} & T. protein & $5.54 \pm 0.42 \mathrm{a}$ & $5.08 \pm 0.21 \mathrm{a}$ & $3.69 \pm 0.52 b$ \\
\hline & & Albumin & $2.99 \pm 0.45 a$ & $2.78 \pm 0.33 a$ & $2.15 \pm 0.28 b$ \\
\hline & & Globulin & $2.55 \pm 0.32 \mathrm{a}$ & $2.30 \pm 0.40 \mathrm{a}$ & $1.54 \pm 0.21 \mathrm{~b}$ \\
\hline & & $\mathrm{A} / \mathrm{G}$ ratio & $1.17 \pm 0.28 \mathrm{~b}$ & $1.21 \pm 0.38 \mathrm{ab}$ & $1.40 \pm 0.23 \mathrm{a}$ \\
\hline \multirow{3}{*}{\multicolumn{2}{|c|}{$\begin{array}{l}\text { Kidney } \\
\text { function } \\
(\mathrm{mg} / \mathrm{dl})\end{array}$}} & Uric acid & $7.23 \pm 0.72 b$ & $7.99 \pm 0.47 b$ & $9.41 \pm 0.55 a$ \\
\hline & & Creatinine & $1.02 \pm 0.21 \mathrm{~b}$ & $1.52 \pm 0.42 \mathrm{~b}$ & $2.13 \pm 0.27 \mathrm{a}$ \\
\hline & & Calcium & $19.42 \pm 0.89 \mathrm{a}$ & $18.67 \pm 0.91 \mathrm{a}$ & $14.18 \pm 0.79 \mathrm{~b}$ \\
\hline
\end{tabular}

Table 4: Effect of sodium nitrite on egg production $\%$, and egg characters in laying hens $(\mathrm{n}=5)$

\begin{tabular}{ccccc}
\hline & Groups & $1 \mathrm{mg}$ nitrite/liter & $4 \mathrm{mg}$ nitrite/liter & $8 \mathrm{mg}$ nitrite/liter \\
\hline & During suppl & $78.21 \pm 1.98 \mathrm{a}$ & $77.26 \pm 1.56 \mathrm{a}$ & $69.31 \pm 1.87 \mathrm{~b}$ \\
\cline { 2 - 5 } $\begin{array}{c}\text { egg } \\
\text { production\% }\end{array}$ & $1^{\text {st } m o n t h ~ p o s t ~ s u p p l ~}$ & $78.86 \pm 1.44 \mathrm{a}$ & $77.98 \pm 1.80 \mathrm{a}$ & $57.60 \pm 1.36 \mathrm{~b}$ \\
\hline \multirow{2}{*}{$\begin{array}{c}\text { Egg } \\
\text { weight }(\mathrm{gm})\end{array}$} & During suppl & $55.11 \pm 1.03 \mathrm{a}$ & $53.42 \pm 1.31 \mathrm{a}$ & $50.10 \pm 1.41 \mathrm{~b}$ \\
\cline { 2 - 5 } $\begin{array}{c}\text { Shell } \\
\text { thickness }(\mathrm{gm})\end{array}$ & $1^{\text {st }}$ month post suppl & $55.08 \pm 1.12 \mathrm{a}$ & $54.13 \pm 1.22 \mathrm{a}$ & $52.12 \pm 1.21 \mathrm{~b}$ \\
\cline { 2 - 5 } $\begin{array}{c}\text { shell weight } \\
(\mathrm{gm})\end{array}$ & During suppl & $28.2 \pm 1.03 \mathrm{a}$ & $26.13 \pm 1.13 \mathrm{a}$ & $23.14 \pm 1.07 \mathrm{~b}$ \\
\cline { 2 - 5 } & During suppl & $7.14 \pm 1.12 \mathrm{a}$ & $27.35 \pm 1.18 \mathrm{a}$ & $26.89 \pm 1.29 \mathrm{a}$ \\
\hline
\end{tabular}

During supplementation 1 st month post suppl.= $1^{\text {st }}$ month post $=$ During suppl supplementation

Table 5: Nitrite residue in liver and kidney $(\mathrm{mg} / \mathrm{kgm})$ in laying hens $(\mathrm{n}=5)$

\begin{tabular}{cccc}
\hline Groups & $1 \mathrm{mg}$ nitrite/liter & $4 \mathrm{mg}$ nitrite/liter & 8mg nitrite/liter \\
\hline Liver & 00 & 00 & $30.18 \pm 1.59$ \\
\hline Kidney & 00 & $0.59 \pm 0.17$ & $48.43 \pm 1.40$ \\
\hline
\end{tabular}

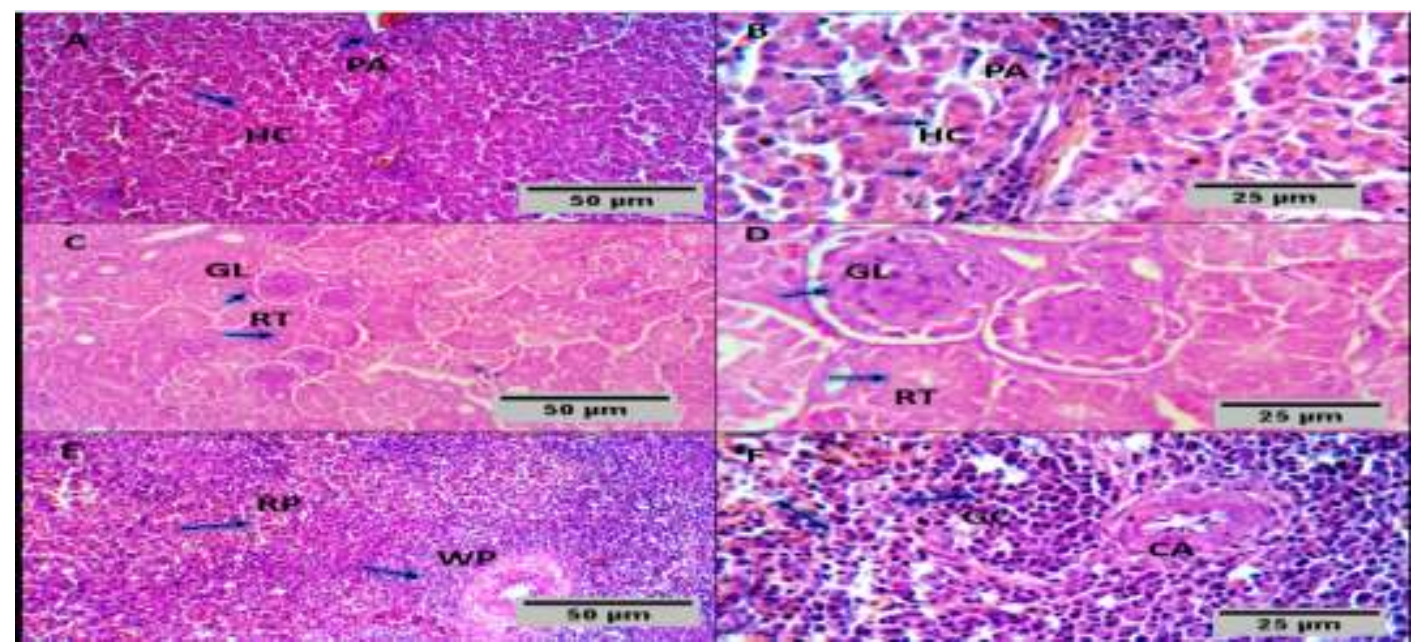

Fig. 1: Hens received one liter of water contains $1 \mathrm{mg}$ sodium nitrite /liter drinking water show

Liver (A,B). Normal histological of different structures, including portal area (triads) (PA, arrow), hepatocytes (HC, arrow) which are seen as an a small masses around the central veins. a few round cells are seen as a natural immune response around the portal area (PA, arrow). Scale bars 50 um, 25 um. Kidney (C,D). Normal histomorphology of the nephron unites, including the tubular structures (RT, arrow), uri-nephric duct and avian glomeruli (GL, arrow). Scale bars 50 um, 25 um. Spleen (E,F). Apparently normal whit (WP, arrow) and red pulp (RP, arrow) with a keeping features of the central arteriole (CA, arrow), germinal centers (GC, arrow) and red pulp sinusoids with their reticulio-endothelial linings. Scale bars 50 um, 25 um. 


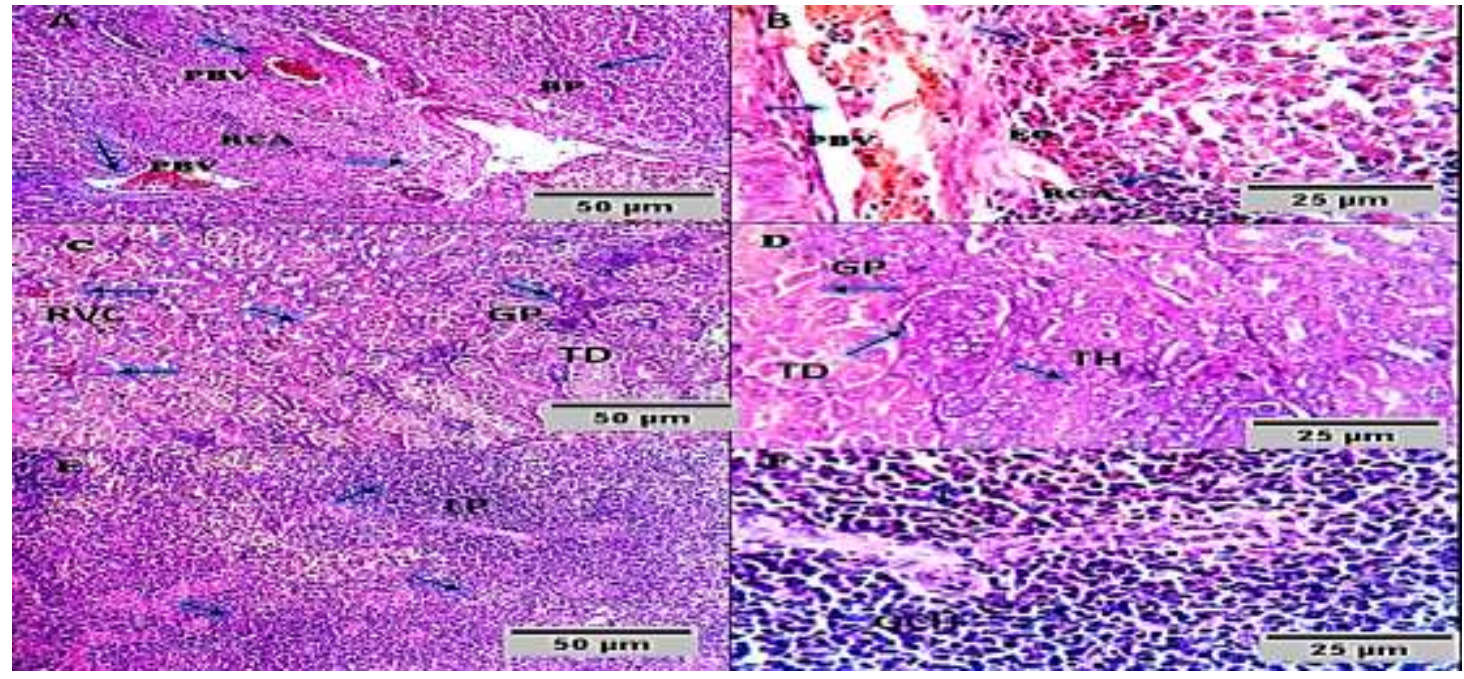

Fig. 2: Hens received one liter of water contains $4 \mathrm{mg}$ sodium nitrite /liter drinking water show

Liver (A, B). Dilated, congested portal blood vessels (PBV, arrow), mild to moderate biliary proliferation (BP, arrow), portal round cells aggregations (RCA, arrow) with a predominance of eosinophils (EO, arrow ) in some areas are seen . Scale bars $50 \mathrm{um}, 25 \mathrm{um}$.

Kidney (C, D). Renal vascular congestion (RVC, arrow), tubular degeneration (TD, arrow), focal tubular hyperplasia (TH, arrow) and focal glomerular endothelio -mesangial cellular proliferation (GP, arrow) are seen. Scale bars 50 um, 25 um.

Spleen (E, F). A reactive mild to moderate germinal centers hyperplasia $(\mathrm{GCH}$, arrow) and periarteriolar sheath lymphoid proliferation (LP, arrow) are observed with a normal structurally organized Red pulp (RP, arrow). Scale bars 50 um, 25 um.

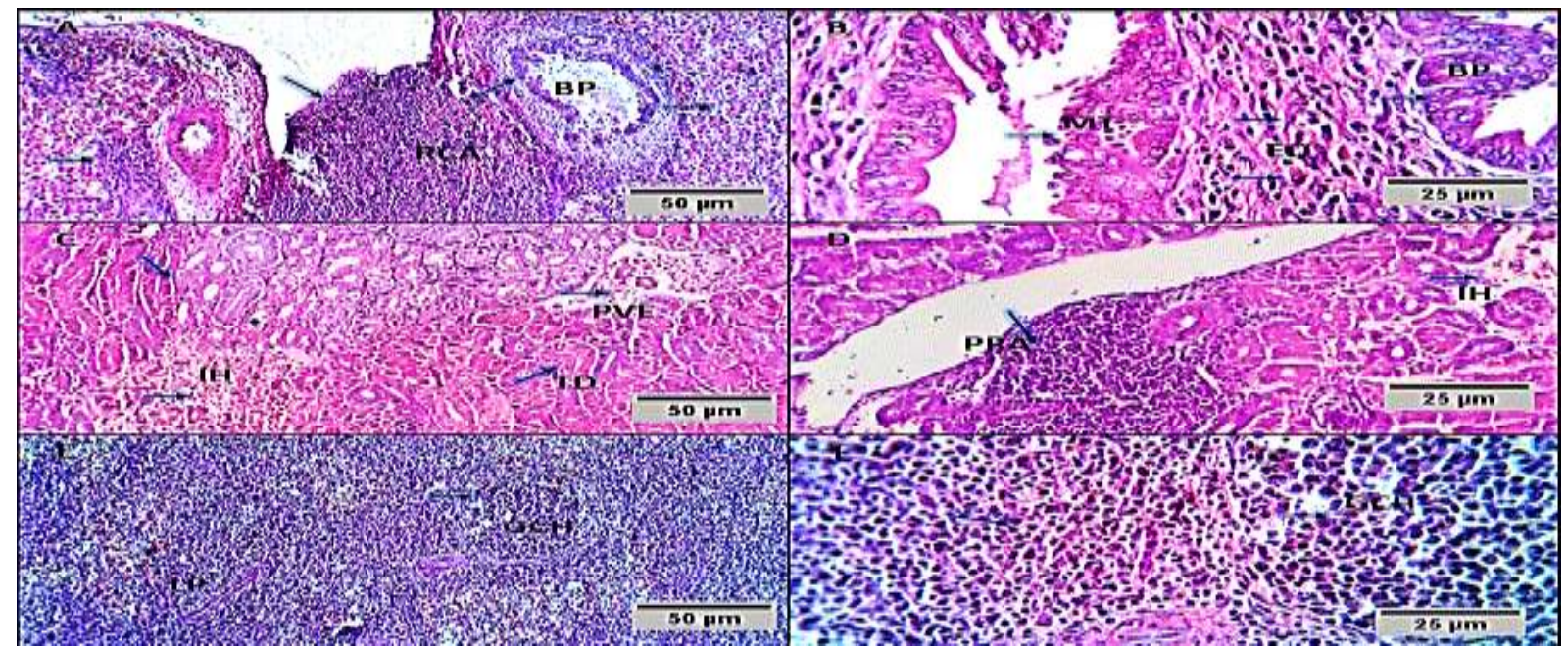

Fig. 3: Hens received one liter of water contains $8 \mathrm{mg}$ sodium nitrite /liter drinking water show

Liver. Demonstrated characteristic marked hepatic histopathologic changes as portal round cells aggrega-tions (RCA), biliary proliferative hyperplasia (BP) with focal metaplastic change (MT) together with portal Fibroplasia and infiltration of eosinophils. Marked interstitial round cells aggregations, eosinophils infiltration and hepatocellular degeneration and individual cellular apoptosis were also encountered. (Fig.3 A, B). Kidney. Histopathological changes were marked in this group; there were perivascular edema (PVE), intestinal hemorrhages (IH) perivascular and interstitial round cell aggregations (RCA) and renal tubular degeneration (RTD) with focal early necrotic changes. (Fig.3 C D). Spleen germinal centers hyperplasia $(\mathrm{GCH})$ and peri-arteriolar sheath lymphoid proliferation (LP) together with focal or diffuse replacement of red pulp by mature and immature lymphocytic, eosinophils infiltration was encountered. 


\section{DISCUSSION}

Analysis of underground well water from different region in Sharkia Province revealed levels of $\mathrm{PH}$, total dissolved solid and nitrite in Diarp Negm were 8.28, 608 and 0.013, Kafr Sakr 8.46, 207.25, 0.05, El Salhia, 8.69, 722.5, 0.63 and Zagazig, 9.85, 1764.33, $34 \mathrm{ppm}$ respectively. The lowest level of these parameters were present in underground well water in Diarp Negm followed by Kafr Sakr then El Salhia but high levels of these parameters were present in underground well water in Zagazig city (Table 1). Same result was recorded by (Talha et al., 2008) stated that Physical, and chemical properties (Phvalues, total dissolved solid and nitrite) were increased in well water due to pollution. Presence and increased concentration of nitrite in underground water well is correlated to high industrial and agriculture wastes (Jennings et al., 1996).

The results of this study revealed that hens received one liter of water contains $4 \mathrm{mg}$ sodium nitrite/liter drinking water for 30 days showed non-significant reduction in $\mathrm{RBCs}, \mathrm{Hb}, \mathrm{PCV}$, WBCs, lymphocyte, Phagocytic activity, total protein, albumin, globulin and egg production beside insignificant increase in $\mathrm{MCH}, \mathrm{MCHC}$, platelet count, AST, ALT, ALP, uric acid and creatinine and significant increase heterophils,. Same change in egg production was observed by Atef et al. (1991) in laying hens. Laying received $4 \mathrm{mg}$ sodium nitrate/liter water reduced in egg production and blood chemistry (Safary and Daneshyar, 2012).

Results of the present study indicate that laying hens received one liter of water contains $8 \mathrm{mg}$ sodium nitrite/ liter drinking water for 30 days showed insignificant reduction in WBCs beside significant reduction in RBCs, $\mathrm{Hb}, \mathrm{PCV}$, MCHC, lymphocyte, Monocyte eosinophils, basophils Monocyte and Phagocytic activity coupled with increase in Platelet count, MCV $\mathrm{MCH}$, hetetrophils (table, 2 and 3). This observation was previously recorded by Kundsen and Jensen (1997) who reported that nitrite induce decrease in RBCs $\mathrm{Hb}$ PCV and WBCs. This reduction in erythrogram may be due to fragility of erythrocytes induced by nitrite (Atef et al., 1991). The decrease in leukocytic count post using sodium nitrite may be due to failure of hematopoietic tissues to produce new leukocyte (Tan et al., 1992). Reduction in blood picture parameters may be due to Oxidative damage of RBCs and lysis or shrinkage of erythrocytes in the blood (Beaupre and Schiffman, 1994). Similar findings were reported by Diazi et al. (1995) in chickens exposed to nitrite. Reduction of $\mathrm{Hb}$ level may be due to nitrites convert the ferrous ion of hemoglobin to ferric ion (Ganong, 1997). Our data clearly reinforced by those obtained by Abuharfeil et al. (2001) reported that mice received sublethal doses of sodium nitrite in drinking water for 21 days revealed significant decrease in dose-dependent in WBCs, lymphocyte $\%$ and Phagocytosis coupled with increase in neutrophil count. Mice received 25 to $100 \mathrm{mg}$ sodium nitrite orally for 21 day induced dose dependent decrease of lymphocyte (Chow and Hong, 2002). Our results came in agreement with (Eman and Fahmy 2006 and Eman et al., 2008) stated that sodium nitrite induced significant decrease in RBCs, Hb, PCV and WBCs in rats. Our data clearly reinforced by those obtained by Gluhchevaa et al. (2012) who concluded that rats received sodium nitrite showed significantly decrease in RBCs, $\mathrm{Hb}, \mathrm{PCV}$ coupled with significant increase in $\mathrm{MCH}$ and MCHC. Our results were supported by Abu Aita and Mohammed (2014) stated rats received sodium nitrite showed significant decreases in RBCs, Hb, PCV, WBCs, MCHC and increase MCV. Nitrite causes methemoglobinemia and reduction in hemoglobin (Gihan et al., 2014). Our data is agreed with Azab et al. (2015) found that Guinea pigs received $80 \mathrm{mg} / \mathrm{kg}$ body weight sodium nitrite daily for 35 days showed significant reduction in RBCs, $\mathrm{Hb}, \mathrm{PCV}$ and WBCs, MCH, MCHC beside increase in MCV. Sodium nitrate induces decrease in RBCs, $\mathrm{Hb}$, PCV and WBCs, lymphocyte and increase in neutrophils (Ashmore et al., 2016 and Khaled et al., 2019).

In the current work, it has been found that laying hens received one liter of water contains $8 \mathrm{mg}$ sodium nitrite /liter drinking water for 30 days revealed significant decrease in total protein, albumin and globulin (Table 3). Nearly smilar results were recorded by Ibrahim et al. (1999) mentioned that nitrate toxicity in duck revealed significant decrease in total protein, albumin and globulin. Another explanation for 
reduction of total protein, albumin and globulin come from Salama et al. (2013) who stated that Sodium nitrite-induced hepatic damage by intensification of oxidative stress and DNA damages and inhibition of mitochondrial function leading to reduction of albumin. Similar result was recorded previously by Eman and Fahmy (2006) and Eman et al. (2008) in rat received of sodium nitrite. The obtained results agree with those reported by Hassan et al. (2009) and Gihan et al. (2014) who stated that Guinea pigs exposed to sodium nitrite were significantly decreased serum total proteins, albumin, and globulin concentration. Reduction in total protein, albumin and globulin may be due to toxic effect of nitrite inducing impaired albumin synthesis by damaged liver cells (Abdel-Rahman et al. 2018). Also, Nagla et al. (2020) reported that adult rats received sodium nitrite induces dose dependent decrease serum total protein, albumin and globulin levels.

The obtained results for serum liver enzymes summarized in table, (3) revealed a significant increase AST, ALT, ALP, uric acid and creatinine beside reduction in calcium level in laying hens received one liter of water contains $8 \mathrm{mg}$ sodium nitrite/ liter drinking water for 30 days. Our results go hand in hand with those reported by Eman and Fahmy (2006) and Eman et al., (2008) stated that sodium nitrite induced increase in liver enzymes in rats. Elevation in uric acid and creatinine is due to kidney injury (El-Sheikh and Khalil, 2011). Nearly similar findings were reported by Safary and Daneshyar (2012) they found that liver enzymes were increased and reduction in calcium level in serum of laying hens received sodium nitrite. Similar result was recorded previously by Imam and Mohammed (2013) stated that sodium nitrite induced liver damage and increase AST, ALT and ALP in rats. Our results were recorded by Mohammed et al. (2014) and Gihan et al. (2014) stated that nitrite significant increase in AST, ALT and ALP in rats. Elevation in liver enzymes may be due to toxic impacts of nitro so-compounds formed in acidic environment of the stomach causing severe hepatic necrosis (Abdel-Rahman et al., 2018). In the same direction, Jeppe et al. (2018) observed that sodium nitrite impaired renal function, and increased uric acid and creatinine. Nitrite induces significant increase AST, ALT, ALP, uric acid and creatinine (Nagla et al., 2020).
The obtained results for some egg parameters were summarized in table (4). The results revealed laying hens received one liter of water contains $8 \mathrm{mg}$ sodium nitrate/liter drinking water decreased egg production\%, egg weight, shell thickness and shell weight. Layers received water high in nitrite produced significant decreased in egg production\% and egg weight and shell thickness (Talha et al., 2008).

Residues of nitrite in liver and kidney beside its dose dependent, Table, (5) showed that the nitrite residues were detected in high levels in kidney more than liver post supplementation. The obtained results nearly coincide with those reported by Kohn et al. (2002) who mentioned nitrite excretion rapidly in urine. These results agreed with Lee et al. (2018) reported that nitrite were detected in high levels in kidney than liver and this may be due to nitrite excreted though urine.

The main gross pathological lesion appeared in laying hens received one liter of water contains $0.1 \%$ sodium nitrite showed liver, Kidney and spleen normal histological characterization of different structures but laying hens received one liter of water contains $4 \%$ and $8 \%$ sodium nitrite showed modert to sever lesion in liver, Kidney and spleen. Same gross pathological lesion was observed previously in mice received sodium nitrite (Sadiq et al., 2018). Goats received $4 \mathrm{mg}$ potassium nitrite/ $\mathrm{kg} \mathrm{b}$. wt orally for 32 days caused dilatation of central vein and sinuso-ids, degenerative changes in periaciner zone, beside hyperplasia, hypertrophy and detachment of epithelium lining of bile duct with mononuclear cell infiltration (Mondal et al., 1999 and Kohn et al., 2002). Pathological finding in our work revealed severe lesion in laying hens received one liter of water contains $8 \mathrm{mg}$ sodium nitrate /liter drinking water but laying hens received one liter of water contains $4 \mathrm{mg}$ sodium nitrate/liter drinking water lesions were mild. Same pathological changes in rat liver (Hakk1 et al., 2009) received sodium nitrite. Sodium nitrate induced shrinked glomerular tuft, degeneration of some tubules and epithelial lining cells. Formation of focal fibrosis and infiltrated with a number of inflammatory cells. Liver showed hydropic degenerated 
hepatocytes, necrotic areas infiltrated with a number of inflammatory cells (Sanaa and Mahmoud 2012). The previous observations were supported by Hasan et al. (2014) found that sodium nitrite induced degenerative changes in liver, kidney and spleen in mice. Same pathological lesions were reported by (Lee et al., 2018) in dogs received nitrite. Pathological changes observed in liver and kidney post using sodium nitrite may be due to reactive oxygen and nitrogen species produced by nitrite (Sherif and Al-Gayyar 2015). Same pathological lesions were reported by Nagla $e t$ $a l$. (2020) in rats received sodium nitrite.

From the previously mentioned results it could be concluded that, high levels of nitrite induce alterations in some hematobiochemical parameters, egg production and induce many pathological lesions. So, not use water contains high levels of nitrite in laying farms.

\section{REFERENCES}

Abdel-Rahman, $\quad H . ; \quad$ Abd-El-Fattah, $\quad$ M.; Youssef, M.; Essawi, E. and Elsedawy, M. (2018): the protective effect of different doses of alpha lipoic acid against hepatotoxicity of sodium nitrite in rat. Int J Dev Res 08(11): 24140-24145

Abu Aita, N. and Mohammed, F: (2014): Effect of marjoram oil on clinicpatholo-gical, and pathological alterations induced by nitrite in rats. Glob Vet12 (5) 606-616.

Abuharfeil, N.; Sarsour, E. and Hassuneh, M. (2001): the effect of sodium nitrite on some parameters of the immune system. Food Chem Toxicol 2001; 39:119-124.

American Public Health Association (APHA) (1999): Standard method for examination of water and wastewater $\left(20^{\text {th }}\right.$ ed $)$. Washington: AWWA/ WPCE. American Water Works Association, Water Environment Federation.

Ansari, F.; Ali, S. and Mahmood, R. (2015): Sodium nitrite-induced oxidative stress causes membrane damage, protein oxidation, lipid peroxidation and alters major metabolic pathways in human erythrocytes. Toxicol Vitr 29(7):18781886.

Anthony, T.; Twin, K.; Erin, M. and Michael, E. (1985):"Phagocytic and killing capacities of utrine derived leukocytes. From mares, resistance and susceptible to chronic endometritis". Am. J. Vet. Res. 46 (9): 1938-1940.

Atef, M.; Abo-Norag, M.; Hanafy, M. and Agag, A. (1991): Pharmacological aspects of nitrate and nitrite in laying hens. British Poultry Science, 32, 99-104.

Ashmore, T.; Fernandez, B.; BrancoPrice, C.; Griffin, J. and Murray, A. (2016): Suppression of erythropoiesis by dietary nitrate. The FASEB J. 29(3): 1102-1112.

Azab, E.; Nuri, M. and Mohamed, O. (2015): Haemato-protective and hypolipidemic effects of libyan propolis against sodium nitrite induced haematotoxicity and hyperlipid-emia in Guinea Pigs. Amer J. of Bios and Bioengineering, 3(4) 22-32

Bancroft, J. and Gamble, M. (2002): Theory and practice of histological technique, $5^{\text {th }}$ Ed livingston, London, Edinburgh, New york, Phildadelphia, St Louis, Syndeg.

Bauer, J. (1982): Determination of Serum albumin. Clinical Methods, $4^{\text {th }}$ Ed., 495496.

Beaupre, S. and Schiffman, F. (1994): Rush hemolysis. A "bite-cell" hemolytic anemia associated with volatile liquid nitrite use. Archives of Family Medicine $3,545-548$

Boyum, A. (1986): "Isolation of mononucle-ar cells and granulocytes from human blood". Canadian. J. Clin. Invest. 21: 7789.

Chow, C. and Hong, C. (2002): Dietary vitamin $\mathrm{E}$ and selenium and toxicity of nitrite and nitrate. Toxicology 180: 195207.

Carlstrom, M.; Larsen, F.; Nystrom, T.; Hezel, M.; Borniquel, S. and Weitzberg, E. (2010): Dietary inorganic nitrate reverses features of metabolic syndrome in endothelial nitric oxide synthasedeficient mice. Proc Natl Acad Sci USA, 107, $17716-17720$

Chu, Y. and Dietert, R. (1989): "Monocytes function in chicken with hereditary dystrophy". Poult. Sci. 68: 226-232

Coalombe, J. and Faurean, l. (1963): determination of urea. Clin. Chem., 9:102-108.

Diazi, G.; Julian, R. and Squires, E. (1995): Effect of dietary nitrite on pulmonary hypertension in chickens and dilatory 
cardiomyopathy in turkey Avian Patho 24, 19-29

Doumas, B.; Cartor, R.; Peers, T. and Schafer, $R$. (1981): A candidate reference method for determination of total protein in serum Clin Chem, 27, 1642.

Duncan, D. (1955): Multiple ranges and multiple "F" test. Biometrics, 11:10.

El-Sheikh, N. and Khalil, F. (2011): L-Arginine and l-glutamine as immunonu-trients and modulating agents for oxidative stress and toxicity induced by sodium nitrite in rats. Food Chem Toxicol 49(4): 758-762.

Eman, H.; Zahkok, S.; Ghada, Z.; Al-Kassas, M. and Abdel, H. (2008): Biochemical studies on the effect of sodium nitrite and/or glutathione treatment on male rats. The Egyptian J. of Hospital Med. 30 (1) 25- 38.

Eman, G. and Fahmy, G. (2006): management the action of sodium nitrite on albino rats by aqueous garlic extract. Res. J. of Medicine and Med. Sci, 1(3)85-89

Forstner, N. and Wittman, G. (1983): "Metal pollution in the aquatic environment" Springer-Verlag, Berlin.

Ganong, W. (1997): Review of Medical Physilogy. $8^{\text {th }}$ ed. Libraure du liban, Appelton of Longe, Lebanon, California: $296-311$.

Gihan, M.; Hammoud, S.; Nail, K.; ELSawy, S.; Abd El-Rahman, S.; Youssef, M. and Mohamed, S. (2014): Protective effect of grape seed extract against sodium nitrite induced toxicity and oxidative stress in albino rats. Az. J. Pharm Sci. 49, (1) 1-9

Gindler, E. (1972): Determination serum calcium level. Am. J. Clin, Path (58) 376.

Gluhchevaa, Y.; Ivanovb, I. and Vladova, I. (2012): Sodium nitrite-induced hematological and hemorheological changes in rats. Series on Biomechanics, 27 (3-4) 53-58

Godeeris, B.; Boldwin, C. and Morrison, W. (1986):"Improved methods for purification and depletion of monocytes from bovine peripheral blood mononuclear cells. Functional evaluation of monocytes in response to Lectins". Imm. Meth. J. 89(2): 165-73.

Haimin, Z.; Shenghong, K.; Yunxia, Z. and andHuijun, Z. (2016): fluorescene determination of nitrite in water using prownshell derived- Nitrogen-Doped carbone
Nondateas fluorophores ACS sensons 1(7) 875-681

Hasan, Ö.; Ufuk, K.; Musa, K.; Süleyman, G.; Emine, A.; Kadir, $\ddot{O}$. and Onur, $A$. (2014): Histopathologic, Biochemical and Genotoxic Investigations on Chronic Sodium Nitrite Toxicity in Mice. Exp Toxicol Path 66 (8):367-75

Hassan, H.; El Agmy, S.; Gaur, R.; Fernando, A. and Raj, M. (2009): In vivo evidence of the hepato-and renoprotective effect of garlic oil against sodium nitrite-induced oxidative stress. Int J Biol Sci; 5: 249-55.

Heihashy, S. and Abd El-Moneim F. (1999): Blood lipid profile and serum free thyroidal hormone concentrations in growing rats fed diets enriched with sodium nitrate for short and long terms. J. Egypt. Ger. Soc. Zool.; 30 (A): 93- 103.

Hakkl, C.; Fatih, F. and Hayati, Y. (2009): protective potential of Yucca schidigera against nitrite-induced oxidative stress in rats..J Natur Med. 63(3): 311-317

Husdan, H. and Roporpot, A. (1968): Estimaton of creatinin. Clin. Chem14, 22

Ibrahim, A.; Zaky, Z.; Sharkawy, A. and Mubarak, M. (1999): Effect of vit. C on nitrate toxicity in ducks. $15^{\text {th }}$ annual conf for Egy. Soci of Toxicol. Alex. Univ.

Imam, O. and Mohammed, M. (2013): Antioxidant and hepatoprotective of silymarin on hepatic dysfunction induced by sodium nitrite. Eur. Cytok Netw. 24(3)14-21

Jain, N. (1993): Essentials of Veterinary Hematology. Lea \& Fibiger. Philadelphia. USA.

Jennings, G.; Sneed, R. and Clair, M. (1996): Metals in Drinking Water. Published by: North Carolina Cooperative Extension service Publication.

Jeppe, B.; Erling, B. and Jesper, N. (2018): the effect of sodium nitrite infusion on renal function, brachial and central blood pressure during enzyme inhibition by allopurinol, enalapril or acetazolamide in healthy subjects: a randomized, doubleblinded, placebo-controlled, crossover study. BMC Nephrology. 19, 326-332

Jensen, $F$. (2007): Nitric oxide formation from nitrite in fish. J Exp Biol 210(19)387-394

John, D. (1982): Determination of Alkaline Phosphates. 9th Ed. 580-581.

Khaled, A.; Mohamed, M.; Yasmine, M.; Gehan, M.; Mona, M. and Ali, Q. (2019): 
Effect of sodium nitrite exposure on the immune responses against rift vally fever vaccine in mice. Inter. J. of Pharm. Pharm. Sci., 11(7) 28-31

Kapale, P.; Badkale, D. and Sahatpre, S. (2008): serum total protein and serum total cholesterol levels in Gaolao veterinary world. 1 (4):15-16

Kohn, M.; Melnick, R.; Ye, F. and Portier, C. (2002): Pharmacokinetics of sodium nitrite-induced methemoglobinemia in the rat. Drug Metabo and Disposiz. 30:676-683.

Kundsen, P. and Jensen, F. (1997): Recovery from nitrite induces dmethaemoglobinaemia and potassium balance disturbances in carp. Fish Physiol Biochem 16:1-10

Lee, S.; Helen, B.; Donald, A.; James, R. and Charles, E. (2018): Secondary poisoning risk for encapsulated sodium nitrite, a new tool for possum control. New Zealand Journal of Ecology 42(1): 65-73

Lundberg, J.; Weitzberg, E. and Gladwin, M. (2008): the nitrate-nitrite-nitric oxide pathway in physiology and therapeutics. Nat Rev Drug Discov 7:156-167.

Ma, J.; Ding, Z.; Wel, N.; Zhao, H. and Huang, $T$. (2009): Sources of water pollution and evolution of water quality in the Wuwei basin of Shiyang river, North-west China. J. of Environmental Management 90 (2): 1168 - 1177

Mondal, D.; Pandey, N. and Charan, K. (1999): Effects of prolonged low nitrite intoxication in goats. Indian Vet. J. 76: 800-803.

McDonald, P.; Edwards, R.; Greenhalgh, J. and Morgan, C. (2002): Anim. Nutr. $6^{\text {th }}$ Ed. Pearson Prentice Hall, Harlow, England

McNally, B.; Griffin, JL. and Roberts, LD. (2016): Dietary inorganic nitrate: from villain to hero in metabolic disease? Mol Nutr Food Res 60(1):67-78.

Mohammed, A.; Sarhan, A.; Shati, A. and Fahmy, G. and Elsaida, B. (2014): Biochemical and molecular studies on the possible influence of Brassica oleracea and Beta vulgaris extracts to mitigate the effect of food preservatives and food chemical colorants on albino rats. Saudi J Biol Sci.; 21(4): 342-354.

Nagla A.; Ahmed, S; Mohamed, A. and Laila, A. (2020): Effects of nitrite on hepato- toxicity and nephrotoxicity, histopathological change in adult rats. Enviro Sci and Pollution Res. 27, 401914032

Ritman, S. and Frankle, S. (1957): determimation of GOT and GPT activity. Am. J. Clinic. Path. 28:56.

Safary, H. and Daneshyar, M. (2012): Effect of dietary sodium nitrate consum-ption on egg production and quality characteristics and some blood indices in native hens of west Azarbaijan Province. Asian-Australas J Anim Sci 25(11)611616

Sadiq, M.; Al-Hiti, A.; Hussain, M. and Ammar, A. (2018): Evaluation of histopathological changes in mice exposed to sodium nitrite for long term by using hematoxylin and eosin staining. Inter. J. of Pharm. Sci. Res. 9(2): 483-89.

Salama, M; Abbas, A; Darweish, M. and AlGayyar, M. (2013): Hepatoprotective effects of cod liver oil against sodium nitrite toxicity in rats. Pharm Biol; 51:1435-1443.

Salem, M.; Eweida, A. and Azza, F. (2000): Heavy metals in drinking water and their environmental impact on human health. ICEHM page 542- 556

Sanaa, R. and Mahmoud, M. (2012): protective effect of Vit A against sodium nitrate toxicity in liver and kidney of albino rats. J Am Sci 8(12):293-308

Scott, M.; Nesheim, M. and Young, R. (1982): Nutrition of the Chicken. $3^{\text {rd }} \mathrm{Ed}$. Humphrey Press Inc., Geneva, New York.

Sherif, O. and Al-Gayyar, M. (2015): Cod liver oil in sodium nitrite induced hepatic injury: does it have a potential protective effect? Redox Rep 20(1): 11-16.

SPSS (2004):"Statistical and package for social sci., SPSS for windows release." Standard version, copyright SPSS Inc., 1989- 2004.

Summers, J.; Grandhi, $R$. and Leeson, $S$. (1976): Calcium and phosphorus requirem-ents of laying hens. Poultry Sci., 55: 402-413.

Talha, E.; Elfadil, A. and Omer, H. (2008): water quality and its effects on productive performance of layers during winter season. Inter. J. of Poultry Sci.7 (5) $37-40$ 
Tan, Y.; Nambiar, R. and Yo, S. (1992): Prevalence of protein calorie malnutrition in general surgical patients. Ann. Acad. Med. Singapore, 21 (3): 334-338.
Wilikinson, P. (1976): "Recognition and response in mononuclear and granular phagocytes". Lin. Exp. Immunol. 25(3): 355-366.

\section{تقييم تلوث الماء بالنيتريت على إنتاج البيض وبعض الوظائف الهيماتوبيوكيميائية بمزارع الاجاج البياض البفض}

\section{ايمان اسعاعيل محدل اسماعيل،أسامة السعيل رمضان ، ماجدة نعدت عبد الحميل ، محمد بلر عبل العظيم النيل ناهد عبل الحفيظ قمورة ، سناء محمد سالم}

E-mail: dr.emanismail201@gmail.com Assiut University web-site: www.aun.edu.eg

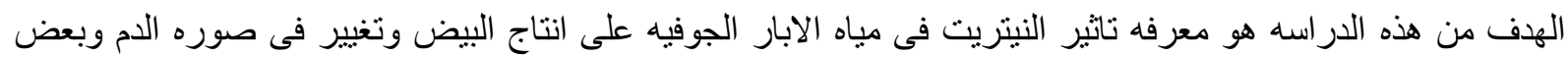

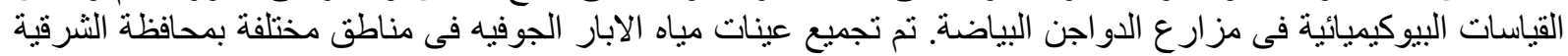

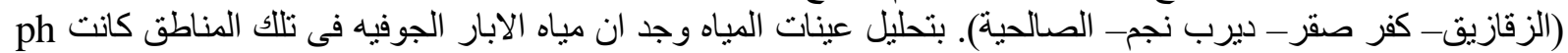

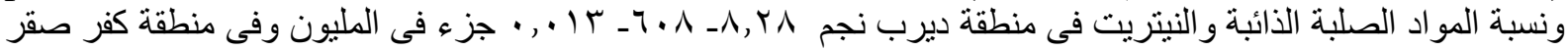

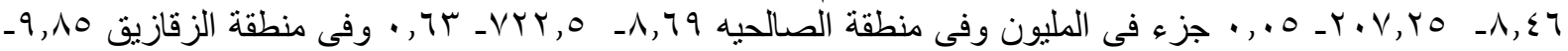

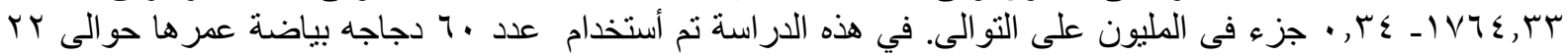

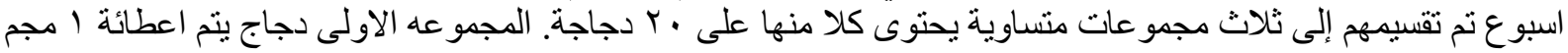

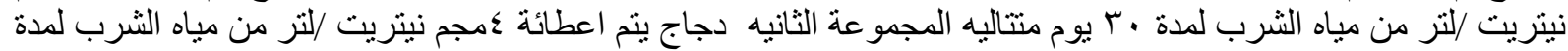

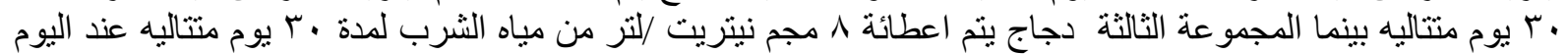

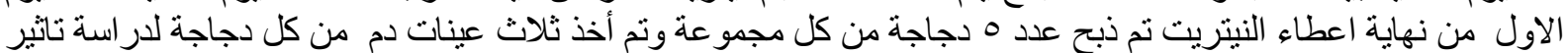

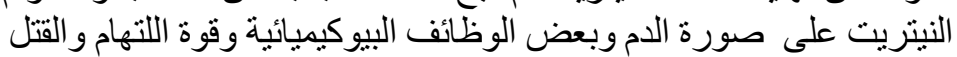

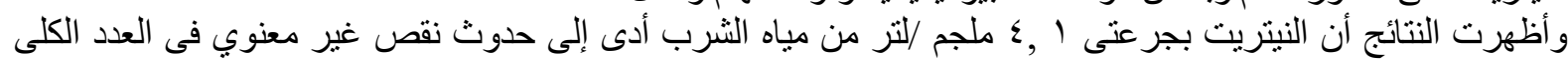

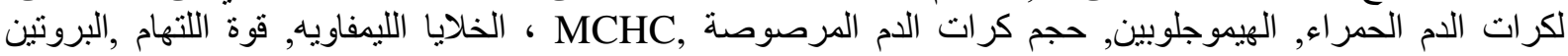

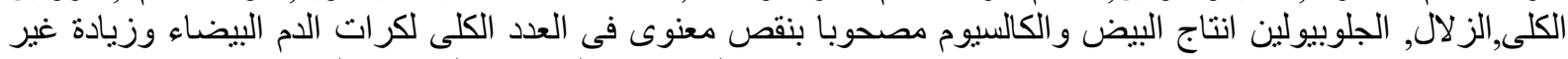

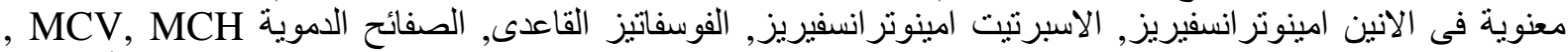

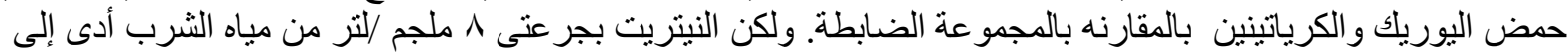

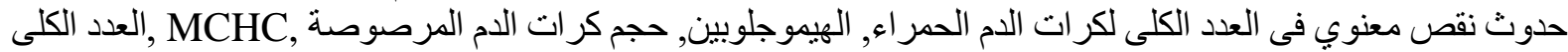

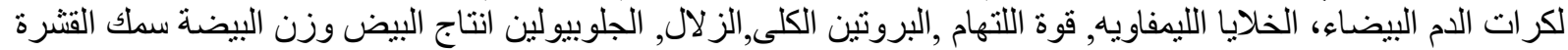

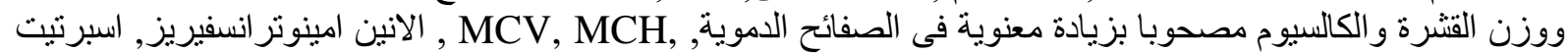

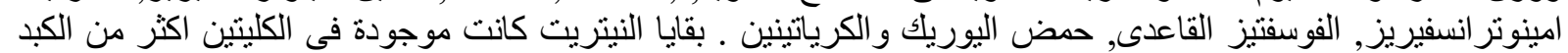

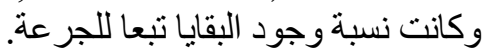

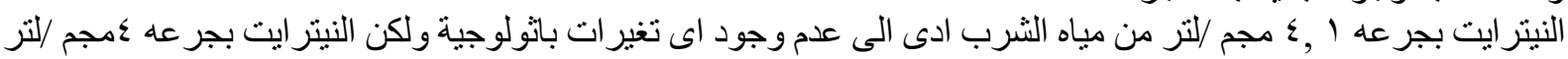

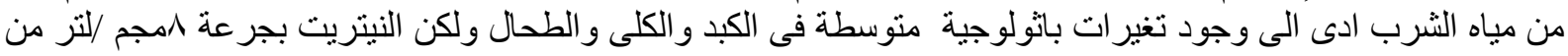

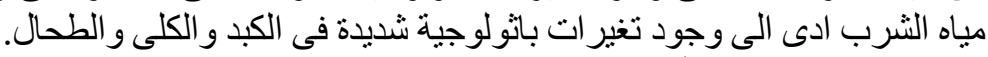

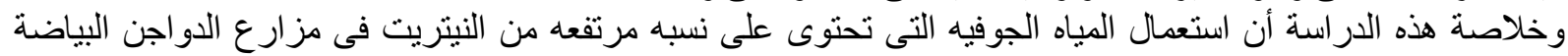

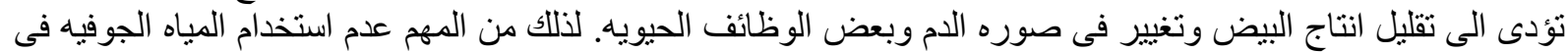

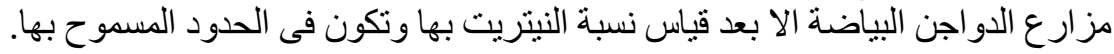

